Danish Journal of Archaeology

\title{
The background of the odal rights: an archaeological discussion
}

\section{Torun Zachrisson}

To cite this article: Torun Zachrisson (2017) The background of the odal rights: an archaeological discussion, Danish Journal of Archaeology, 6:2, 118-132, DOI: 10.1080/21662282.2017.1371440

To link to this article: https://doi.org/10.1080/21662282.2017.1371440

册 Published online: 20 Dec 2017.

Submit your article to this journal $[\pi$

Џ Article views: 11

Q View related articles $\square$

View Crossmark data ¿ 


\title{
The background of the odal rights: an archaeological discussion
}

\author{
Torun Zachrisson \\ Department of Archaeology and Classical Studies, Stockholm University, Stockholm, Sweden
}

\begin{abstract}
The age and origin of the odal rights known from medieval times in Sweden and Norway are debated. Archaeologists tend to view them as old and a part of the pre-Christian society, whereas historians and legal historians view them as established after Christianity was introduced, mirroring canonical laws. In Viking Age runic inscriptions from the eleventh century in the lake Mälaren valley in Sweden, from late tenth to eleventh century in south-western Norway, the term odal, inherited family land occurs together with other expressions concerning landed property. Furthermore, two runestones in Småland and Hälsingland in Sweden, c. $650 \mathrm{~km}$ apart, each enumerate five earlier ancestors in a male lineage, the sponsor himself being the sixth generation. As these runic inscriptions were made in different parts of Scandinavia during the late tenth and eleventh century, this indicates that the term and concept odal was widespread already before the canonic laws of the early medieval period were introduced, and quite possibly belongs to an older inheritance structure. The aim of this article is a renewed discussion focussing on the runological sources where the term and concept odal can be found in the Viking Age Scandinavian society (c. 750-1050 CE), but also early medieval written sources. Thereafter, archaeological sources from the Late Iron Age are addressed (c. 550-1050 CE).
\end{abstract}

ARTICLE HISTORY

Received 27 April 2017

Accepted 22 August 2017

\section{KEYWORDS}

Runic inscriptions; property rights; odal; burial mounds; allodial land; burial rights; lineage

\section{State of research}

Ownership of land can be defined as the right to more permanently decide and dispose of the land. In pre-Christian times, such claims were reflected in visible graves and oral traditions connected to them. The oðal ${ }^{1}$ right known from medieval times in Norway and Sweden concerns the individual landed property of a family. Land would count as odal if it had been passed down through five generations of the same family, and became odal in the sixth, as the older Gulathing Law of early twelfth century western Norway states. Requirements were relaxed somewhat and according to the Frostathing Law of central Norway of the late twelfth century, only three generations were needed (NGL I, 91, 237; Robberstad 1967, Lindkvist 1979, p. 142, Gurevich 1992, p. 194). This right was not dependent on the size of the property, but a direct result of the individual's relationship to earlier generations (Gurevich 1985, p. 45). Odal could also comprise waters and stationary fishing works that belonged to the land (Hafström 1962, p. 502, Robberstad 1967, p. 493). Sons inherited shares in odal land, while daughters did not share in the family land, but inherited outlying land (Sjöholm 1988, p. 128).

Several historians and legal historians agree that the concept of odal existed in pre-Christian Scandinavia. A general opinion however is that a proper right - odelsret - was only established after land started to be bought and sold (e.g. Robberstad 1967, Helle 2001, p. 119f). The odelsret prevented the inherited land from being sold without the consent of the relatives; if land nevertheless was sold, they had a right to redeem it. It is known from the provincial laws in Sweden as bördsrätt, and in Danish laws as lovbydelse (Gelting 2000). This type of right is known also from France and Germany (Norseng 1987, Gelting 2000, see Vogt 2010, p. 209-211). As the odelsret seems to follow the limitations of kinship in the canon law, legal historians generally consider it to have reached its final form after Christianity was introduced (Vogt 2010, p. 211-215 for a full discussion). Historian Knut Helle likewise considers the odelsret as connected with the Christian social order. When the Gulathing Law requires that land should have passed through six

CONTACT Torun Zachrisson torun.zachrisson@ark.su.se EDepartment of Archaeology and Classical Studies, Stockholm University, SE-106 91 Stockholm, Sweden

(c) 2017 The Partnership of the Danish Journal of Archaeology 
generations, it is probably connected to the fact that marriage between relatives was not accepted until the seventh generation (Helle 2001, note 18).

Legal historian Helle Vogt has expanded the discussion by suggesting that one of the aims of the introduction of legislation in the Scandinavian kingdoms was to establish an 'ecclesiastical definition of kinship'. This canonical kinship is viewed as an alternative to the more loosely defined kinship ties based 'on blood, friendship and alliance'. Although stressing that the borders between the two types of kinship systems were fluid, she regards the Viking Age social structure as frail and lacking a firm definition of kinship. Instead, it was characterized by its elective- and alliance-based kinship (Vogt 2010, p. 11-14, 259).

Contrary to this, there is a widespread opinion among archaeologists and some historians of religion in Sweden and Norway that there existed a property right during at least the Viking Age that was called odal (e.g. Skre 1998, Iversen 2004, Bratt 2008, p. 161, Löwenborg 2012, Sundqvist 2016, p. 448). I have earlier argued that inherited rights were articulated and manifested, especially through grave mounds at burial grounds of farms and manorial estates in the Late Iron Age (c. 550-1050 CE), and that these types of manifestations could be connected to the concept of odal (Zachrisson 1994). The fact that the term odal is widespread among the Germanic languages speaks for its old age, but also underlines its complexity. From the viewpoint of the odelsret/bördsrätt only, it has been argued by Christer Winberg that bördsrätt cannot be reduced to a mere right in cases when landed property was unrightfully sold. In the written law cases, bördsrätt carried a double meaning - either potential right to ownership or actual ownership (Winberg 1985, p. 237-239, see also Vogt 2010, p. 210). That in itself implies that the concept of odelsrett - actual odal could be embedded in the inheritance traditions and social framework of pre-Christian Scandinavia. The legal society of Viking Age Scandinavia has been in focus lately in the Assembly-project (Sanmark 2017) and there is a renewed interest in early law in Scandinavia (e.g. Brink and Collinson 2014) which encourages a discussion on land rights on the background of the legal Viking society.

Methodologically, the vision that chaos and disorder was at hand before the Late Viking Age when
Christian rulers came to power and gradually established law and societal order, also concerning inherited family land may seem attractive. But the archaeological source material from especially Sweden and Norway: data from the Late Iron Age agrarian landscape, from burial grounds in Norway and Sweden and the knowledge about the social order of Scandinavia offers resistance to this view (e.g. Foote and Wilson 1970, p. 80-82, Øye 2002, p. 226-228).

If the odal rights were a late 'loan' and influence from the Roman Catholic Church, it is difficult to understand why the concept could have spread so quickly and be found in different parts of the Scandinavian countries already early in the eleventh century as will be shown below. These runic inscriptions also indicate that the words used for expressing odal rights may have been taken from the oral predecessors of the written laws. Was the number of generations enumerated, a trait that rested on the canon law only? Or could the same amount of generations be articulated when property rights were defended already in the Late Iron Age? And these inheritance rights were named odal by the contemporary society? Below I will try to address these questions, but first some words about the concept odal and its historic roots.

\section{The word odal}

Old Norse odal is usually understood as inherited landed property, family estate, allodial property (Taranger 1913, p. 159f, de Vries 1961). The word odal attested in Swedish runic inscriptions is likewise translated as 'odal (jord)' (Peterson 2006). Linguistically, it is related to words like ädel, noble and adel, nobility (Robberstad 1967, p. 493-494). Etymologically, the word is of unclear origin, but may indicate some sort of identification between the inherited land and the deceased relatives from which it derived (Foote and Wilson 1970, p. 81). The fact that the word is widespread among the Germanic languages - Protogermanic, Old High German, Old Saxon, Old Anglo-Saxon, Old Nordic etc. - speak in favour of its old age. The last rune in the early runic alphabet that emerged c. 0-100 CE was called odal (Williams 1996a, 1996b, Fischer 2005, p. 47), while the first rune $\mathrm{F}$ was called fé, 'wealth', 'cattle'. Movable wealth and landed 
property, of fundamental importance for Germanic peoples, thus marked the beginning and end of the elder futhark (Eriksson and Strid 1991, p. 12). Although it is assumed that the rune names go back to the time of the creation of the runic alphabet, they are however not preserved from this early date. The Old English names are known from Anglo-Saxon and Continental manuscripts from the eighth century and the Scandinavian names from the ninth century (Düwel 2001, p. 197-202). However, the O-rune does not occur in Scandinavian runic inscriptions to denote the word odal.

It goes beyond the frame of this article and my knowledge to set the concept odal in a Continental framework and compare it with the concept of allodial land, inherited family land, known from the early Germanic laws. These laws favoured male lineages and in principle denied women of control of landed property, of inherited family land (e.g. Nelson and Rio 2013, p. 111). This gave effect also on who was allowed to come to power, and how royal successions took place. The northern part of Scandinavia is often, also by us scholars working with it, thought of as a periphery that only gradually received modernity. But, we always tend to underestimate the social structure of the time, and the farreaching networks these societies were involved in. In the period after c. $550 \mathrm{CE}$, there were very close connections between the Anglo-Saxon realm, Merovingian France and Mid-Sweden (Vierck 1981, p. 94, Ljungkvist 2008, Näsman 2008, p. 39). Fostering, marriage alliances, trade networks, hostages, members of warbands, part-taking in foreign body-guards, craft-exchange are all examples of contacts that very likely took place which opened up for a wider transmissions of ideas around property rights.

\section{Written sources connecting with a pre-Christian setting for the concept odal}

The Icelandic writer and chieftain Snorri Sturluson (1179-1241) describes holdar as 'yeomen who have full status as regards their lineage and all their legal rights' (Snorri Sturluson Edda p. 129). According to him, the Norwegian kings perceived the kingdom and the country as their odal. Óláfr Tryggvason (r. 995-1000), Snorri wrote, was ódalborinn til konungsdóms (c. 1230, Heimskringla II, Ísl. Fornr. 27, p. 47, 1992, p. 38, Snorri Sturluson Heimskringla). Odalborinn, 'by birth entitled to the kingdom', foðurarf 'paternal inheritance' and langfeðgatall, 'people who follow each other, the son after the father of the same lineage' occur in the same text about Óláfr Haraldsson (r. 1015-1030, Heimskringla II, Ísl. Fornr. 27, p. 43f, 1992, p. 35), which demonstrates the strong link between the royal genealogies and the country/kingdom as paternal inheritance (Sundqvist 2002, p. 174f). That kingship was thought of as odal, is attested in eleventh century scaldic poetry (Sundqvist 2016, p. 451).

For a long time, Snorri Sturluson's texts were considered useless as sources for the Scandinavian preChristian society, as they are indirect sources, written by him, a Christian, more than two hundred years after the conversion of Iceland (Sundqvist 2016, p. 23-25 for a discussion). Likewise were the provincial laws of Scandinavia thought to mirror canonic laws and reflect almost nothing of the Late Iron Age legal society of Scandinavia (Sjöholm 1988). Today, these written sources are used critically in combination with a source-pluralistic method thereby not totally rejecting or totally approving them, but moving forward in a middle way, sorting different time layers and contexts not least by the identifiable material objects and actions referred to (Sundqvist 2016, p. 25).

If a person's property rights were threatened in medieval times, the individual should orally declare his lineage back to heathen times. This was done by 'enumerating the ancestors possessing the land from the time of the burials in mounds' til haugódals at telia, as it is formulated in Magnus Lawmender's Norwegian Law of the Realm (1274) (MLL, ch. 16) or langfedga tall. till haughs ok till heiðni 'count the ancestry back to the mound and heathen time' as Håkon V's Law (1316) declares (NGL III, p. 121). The right had to be defended through oral memory, and the grave mound held a special position as the materialization of a family's affiliation to the land (Gurevich 1985, p. 45). Old Swedish provincial laws from the Middle Ages, as the Older Västgöta Law (1225) mentions settlements of special dignity høghae byr ok af heðnu bygdaer 'villages with burial mounds settled in pagan times'. This expression also occurs in the Östgöta Law (1290), gör by ok gamall, høgha byr ok heðnu byr, 'a village, settled and old, village with mounds and from pagan times' (Svenska landskapslagar Ä VgL, J, 339, 
ÖgL, B, 217). This implies that the potential right to ownership and the actual right both were perceived as having been established in heathen times. The grave mound seems to have had a symbolic role in inheritance claims regarding landed property.

Medieval Norwegian laws state that if two persons claimed odelret a trial was held, in which genealogies played a fundamental role. This type of conflict is addressed in the Eddic poem Hyndluljód, the lay of Hyndla and set in a pre-Christian divine context. In the poem, Ottar is challenged by Angantyr, and has to describe his lineage to win the lawsuit, which is determined by arbitration by a genealogical investigation. The goddess Freyja, who has doubts about him being a descendant from the gods, questions Ottar. Hyndla helps Ottar remember and rehearse his lineage, and he has to give account for his ancestors, both maternal and paternal as well as ties to the royal families of the Nordic realms: the skilfingar, ynglingar and skjoldungar (Gurevich 1992, p. 190f, Sundqvist 2002, p. 172f, Cöllen 2011, p. 202). Ottar has to enumerate his five ancestors: Innsteinn, Álfr, Úlfr, Sæfari and Svan raudi, and he himself being the sixth generation (Brink 2002, p. 104). He thus acts as is stated in the Gulathing Law: 'Now when the doom is set, (the claimant) shall enumerate his ancestors, the five who have owned the land, and the sixth who had it both in ownership and in odal' (Brink's translation cited Sundqvist 2002, note 187).

Above all does the Old Norse god Heimdallr represent ideas on descent and order, thus personifying many of the aspects linked to the concept odal (for a full account, see Cöllen 2011, p. 201-219). The documented traditions on the god reflect his quality as ancestor. Heimdallr has long been regarded as an enigmatic god, but as has been shown the god quite probably represented a more clearly definable and eminent figure in pre-Christian time, than previously thought (Cöllen 2011).

\section{The late Viking Age runic inscriptions mentioning odal}

One of the most famous runic inscriptions that explicitly mentions odal is found in Nora, Danderyd parish in Uppland, Sweden (U130, Figure 1$)^{2}$. The inscription states that: 'Biorn, Finnvið's son, had this rock-slab cut in memory of Olæif, his brother. $\mathrm{He}$ was betrayed at Finnheiðr. May God help his spirit. This estate is

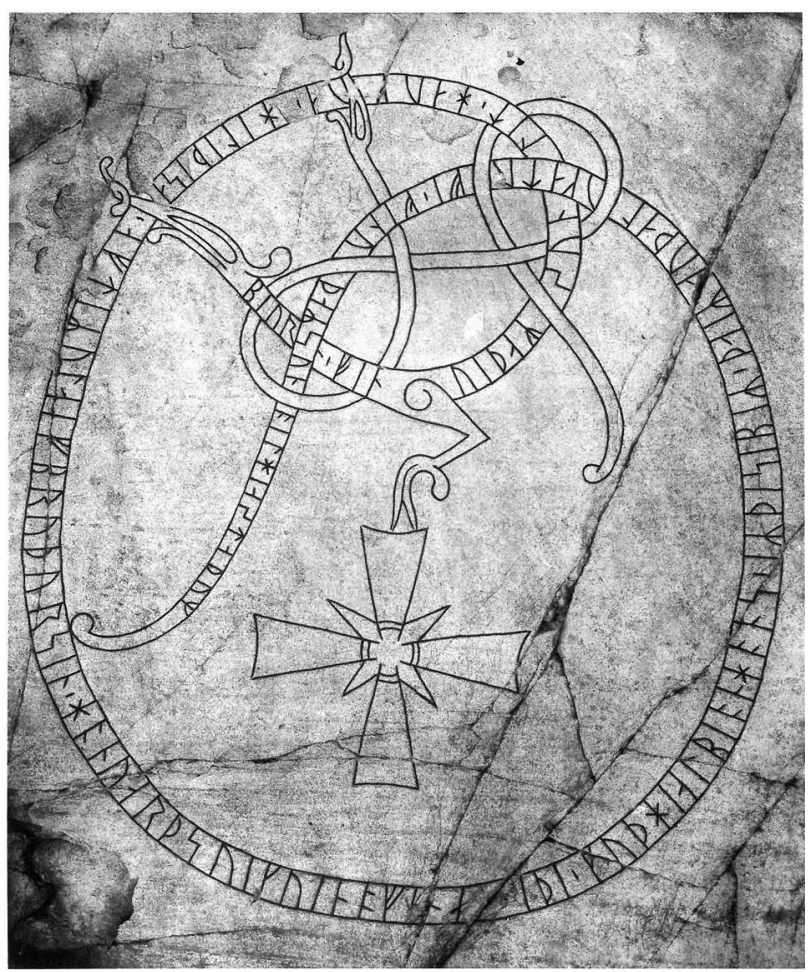

Figure 1. The word pair oðal ok ættærfi is found in the upper right part of the inscription from the crack in the stone to the left part of the loop made by the smaller snake. This means that the first part of the inscription, from the rune animal's head and onwards, which carries the name of the sponsor biorn finnviðar sun 'Biorn, Finnvið's son' enters under the rune ribbon at the word ættærfi 'family inheritance' (U 130 Nora). Photo: H. FaithEll, 1934, ATA.

the allodial land and family inheritance of Finnviðr's sons at Ælgiastaðir. 'Er pessi byR poiRa oðal ok ottcerfi, FinnviðaR suna a Elgiastaðum'. The inscription is placed on a rock by the Viking Age shoreline at the bottom of the harbour bay at Nora. The main farm however seems to have been Älgesta, since the brothers call themselves Finnvid's sons of Älgesta. This settlement is situated $36 \mathrm{~km}$ to the northwest. There Björn had a runestone raised over himself (while he was still alive): 'Biorn, FinnviðaR sunn, let roisa stoein aftiR sik sialfan' (U433); presumably to declare his rights to Älgesta. Both inscriptions were probably hewn c. 1070-1100 CE (Gräslund 2002, p. 144).

Why was it necessary to state: allodial farm and family inheritance? Did the words have different meanings or were they synonymous and intended to give extra power to the expression? The runologists Elias Wessén and S. B. F. Jansson state that arve 
in ancient Swedish and Danish implies inheritance, inherited estate, landed estate, as well as inheritance ale (the inheritance ale/beer, i.e. the name of the burial feast, U130). I have earlier suggested that cettoerfi could stand for the more concrete of the two words and be synonymous with the inheritance as well as the rituals by wich the inheritance was handed over to the next generation. Odal, I then argued, would stand for the more abstract of the two and signify the odal right (Zachrisson 1994, p. 6). The type of word-pair and alliteration oðal ok cettcerfi are however found in the law codes in the provincial laws where they often can denote a uniform concept, like arf ok orf, eld ok oril, lip ok lepung, rop ok rep (UpL Kg comment 30, Ä comment 39, Brink 2005, cp. Ståhle 1956, 1958, 1965). It has been discussed in detail if these types of rythmic structure and alliterations are old, or instead young, learned contributions to the law. Today, it is agreed that alliteration was used in medieval writings, but could also be regarded as an archaic level in provincial laws (Brink 2005, p. 93, 98). It is thus quite possible that the expression oðal ok oettorfi belongs to an oral legal context and that Björn strengthens his case by using the type of mnemonic tools that were in use in the oral past of the predecessors of the written laws.

In Eneby in Runtuna in Södermanland, a now lost runic inscription (Sö145, Figure 2) declared: 'Tosti (and) Øystæinn, they raised (the stone) in memory of Tóki. The sons made in memory of their able father. Tóki owned half of the estate, Grímulfr owned (the other) half of the estate as ancestral allodial land'. The runestone was carved on both sides. It is depicted in Rannsakningar efter antiquiteter (1969, p. 18), around the year 1683 ). The most important source for the Eneby stone is the woodcut in Bautil produced by Johan Peringsköld and Johan Hadorph two years later, in 1685. There the runestone can be seen standing at Eneby, by the road with the church in the distance, and also by the brook that constituted the settlement boundary to the south (compare lantmateriet, the historical maps from Runtuna, Inneberga village 1687, and Eneby village from 1769). Normally, one would have anticipated that the runestone would have been placed with the beginning of the inscription facing towards the road (side $\mathrm{A}$ ), but instead the second side where the property rights concerning the village were clarified was what met the people passing by (side B) 'Toki atti by(?) halfan(?), GrimulfR atti halfan(?) by (?) alda(?) oðali(?)' [: tuki: ati: ru harfan: krimulfu:: ati: hafan: iu: ata i:: upuli]. The word odal has been given special attention. It is found in the centre of the composition on the stone, placed on a rune staff crested with a schematic head of a rune-snake flanked with palmettes; a symbol for the cross that will flourish, that is the resurrection (Zachrisson

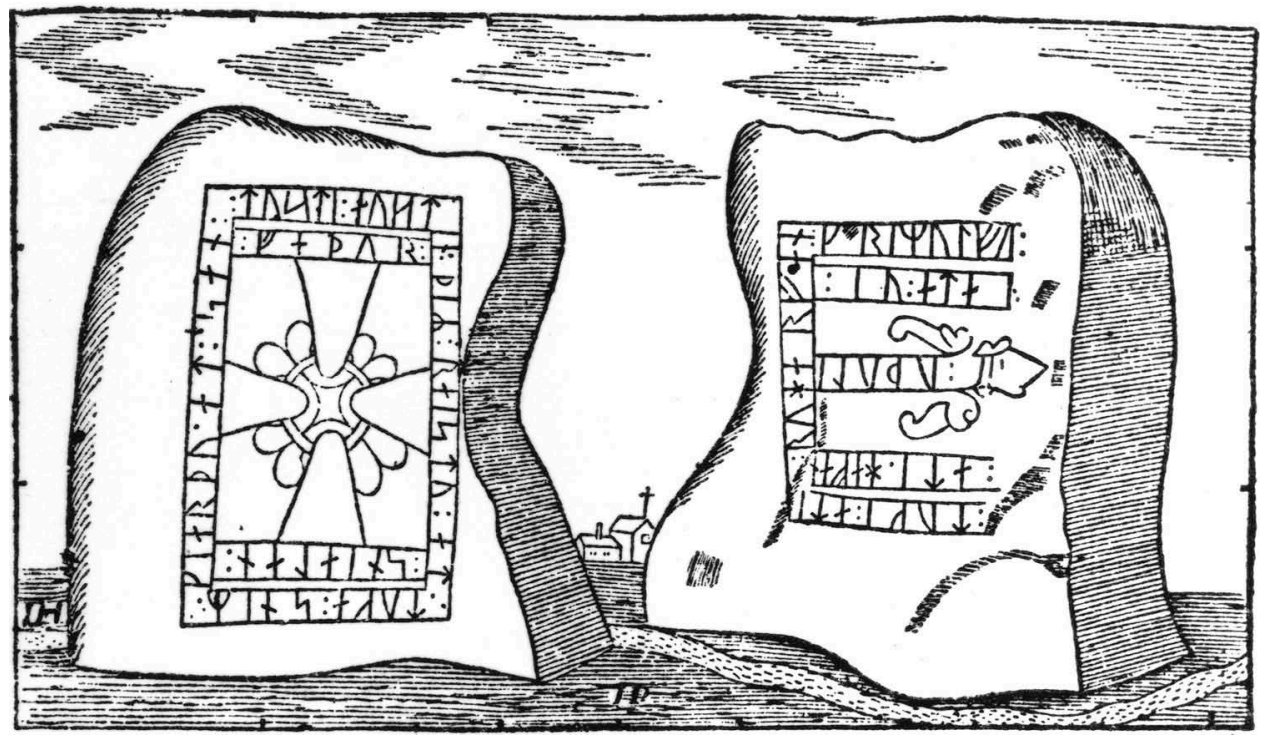

Figure 2. The word odal is placed on the side of the runestone that was facing the road, i.e. to the right in the woodcut. The runes, upuli odal, allodial land, are found in the centre of the composition, on a rune staff crested with a schematic head of a rune-snake flanked with palmettes. Sö 145 Runtuna after Bautil a wood cut by Johan Peringsköld and Johan Hadorph from 1685. ATA. 
1998, p. 142). This ornamental style is used on the oldest zoomorphic runic inscriptions of the type called Pr1 dated to c. 1010-1040 CE (Gräslund 1992, p. 143).

Helmer Gustavson has briefly discussed the inscription and the drawing in Rannsakningar: Toki ati by halfan. GrimulfR ... ati halfan oðal' [ati should be atti] Gustavson interprets as 'Toke owned half the village. Grimulv ... owned half as allodial property'. He thus leaves iu: ata i: (see above) out of the translation (Gustavson 1995, 113-124). Sophus Bugge suggested in Runverser that ata in ata i:: upuli would mean otta(r), but Erik Brate found it more plausible that $\mathbf{i}$ is a misinterpreted line of the runic ribbon, and that $\mathbf{l}$ had been dropped before the $\mathbf{t}$ giving the word alta (Södermanlands runinskrifter1924-36, p. 82). The expression ata upuli should therefore, he argued, be understood as alta upuli, the old lawterm OSwe alda oðal (Svenska landskapslagar, UpL J I.). Brate's interpretation is currently used for instance in the Scandinavian Runic-text Database.

The road that passed by the runestone was one of the main roads (Strängnäs-Nyköping) through the province of Södermanland, probably also used as Eriksgata, the ceremonial journey of the medieval kings (see Sundqvist 2002, p. 316f). At the brook where the runestone stood raised, there is a smaller road leading south-east to the royal manor UppHusa (Oppusa)/Torsberga, neighbour to Eneby. The royal estate Upp-Husa houses a most prominent grave mound from the Iron Age: 'Uppsa kulle' is the third largest preserved mound in Sweden, and measures $55 \mathrm{~m}$ in diameter and $9.5 \mathrm{~m}$ in height. The mound is very exposed in the landscape above the strait Lövsund and the waterroute Runnviken. Mounds of these monumental dimensions usually belong to the period 550-625 CE; this one however, has not been excavated (Lamm 2006, p. 530, Bratt 2008 , p. 65 , Ljungkvist 2008 , p. 277). In the close vicinity of Eneby, there were apparently other types of estates than the ordinary farms, and therefore it might have especially important to be clear about the fact that the property was old allodial property.

The expression alda oðal on the Eneby runestone has parallels in the old Swedish provincial laws. It might have been an expression used in lawsuits at Aspa löt, the assembly site of Rönö hundred, situated $5 \mathrm{~km}$ north of Eneby löt. This assembly site consists of a thing-mound and several Viking Age runestones, one of them mentions that the runestone stands at the thing-place: Stoeinn saRsi standr at Øpi a pingstaði at poru ver. 'This stone stands in memory of CEpir, on the Assembly-place in memory of Póra's husband' (Sö137). This runic inscription belongs to the early phase of the Late Viking Age runestone tradition, just like the Eneby stone, indicating that the thing-place was in use when the Eneby runestone was erected (Sö 137, Vikstrand 2015).

The runic text stated that Toke and Grimulf of Eneby each owned half of the village, and that at least Grimulf's part was old odal. This might be regarded as if a division of the odal land had occurred (Rønneseth 1975, p. 181). To own half a village is mentioned in yet other runic inscriptions. In Släbro, some $30 \mathrm{~km}$ from Eneby, another runic inscription stated that Hamundr, UlfR roispu stoein pennsi aftiR Hrolf, faður sinn, Øyborg at ver sinn. PœiR attu by Sleðabro, Frøystoinn, HrolfR, prottaR pegnaR. 'Hamundr (and) Ulfr raised this stone in memory of Hrolfr, their father; Øyborg in memory of her husband. Frøystæinn (and) HrolfR, pegns of strength, they owned the estate of Sleðabrú' (Sö 367). Another runic inscription from Lerkaka in Runsten parish on Öland (Öl 37) in southern Sweden states that Atti Unn hiar halfan by, that Unn here owned half the village, also named Rich-Unn (cf. Selinge 2010, p. 52f).

At Oddernes in Vest-Agder in Norway, Øyvind, St Olav's godson, had a church built on his odal. 'Eyvindr, godson of Ólafr the Slippery/Crooked/ Holy made this church on his allodial land' (N210). Eyvind has been identified with Eyvind Urarhorn, born c. 985 CE, mentioned in Snorri Sturluson's Kings' Sagas. The runic inscription may thus date to the beginning of the eleventh century. In Sele, Jæren, in Rogaland a runestone mentioning fishing places 'as property and as allodial land' ... at aign auk at opli (N236). The Viking Age runestones of Rogaland probably date to the late tenth or early eleventh century (Krövel 2001, p. 212).

A male or female called Óðalfreðr or Óðalfríðr (u) talfripR has sponsored a runestone around $c$. 1010-1040 CE placed at Åkerby church in central Uppland in Midsweden: 'Óðalfríðr/Óðalfreðr raised these stones in memory of Styrr, her/his father. May God help their spirits. Brandr cut the runes'. Odal 
was normally not used as prefix in Nordic personal names from the Viking Age, except in this case (Peterson 2007, p. 170-171). It is however used on the Continent around the same time, and a man Odalfrid was for instance the chancellor of the east Frankian king Konrad I (r. 911-918; Struck 1990, p. 53).

\section{Genealogies presented in runic inscriptions}

In Norra Sandsjö, Njudung in Småland Ärinvard had a runestone raised in the early eleventh century (Sm 71, Figure 3, Gräslund 2002, p. 154). This runestone was erected untraditionally, on top of a ridge overlooking the lake Sandsjön (Figure 4). The ridge belonged to the settlement Sandsjö, where a church later during the twelfth century was to be built (Ullén cited Zachrisson 2002, p. 35-45). The grounds south of the ridge carry traces of a complicated land use, according to agrarian

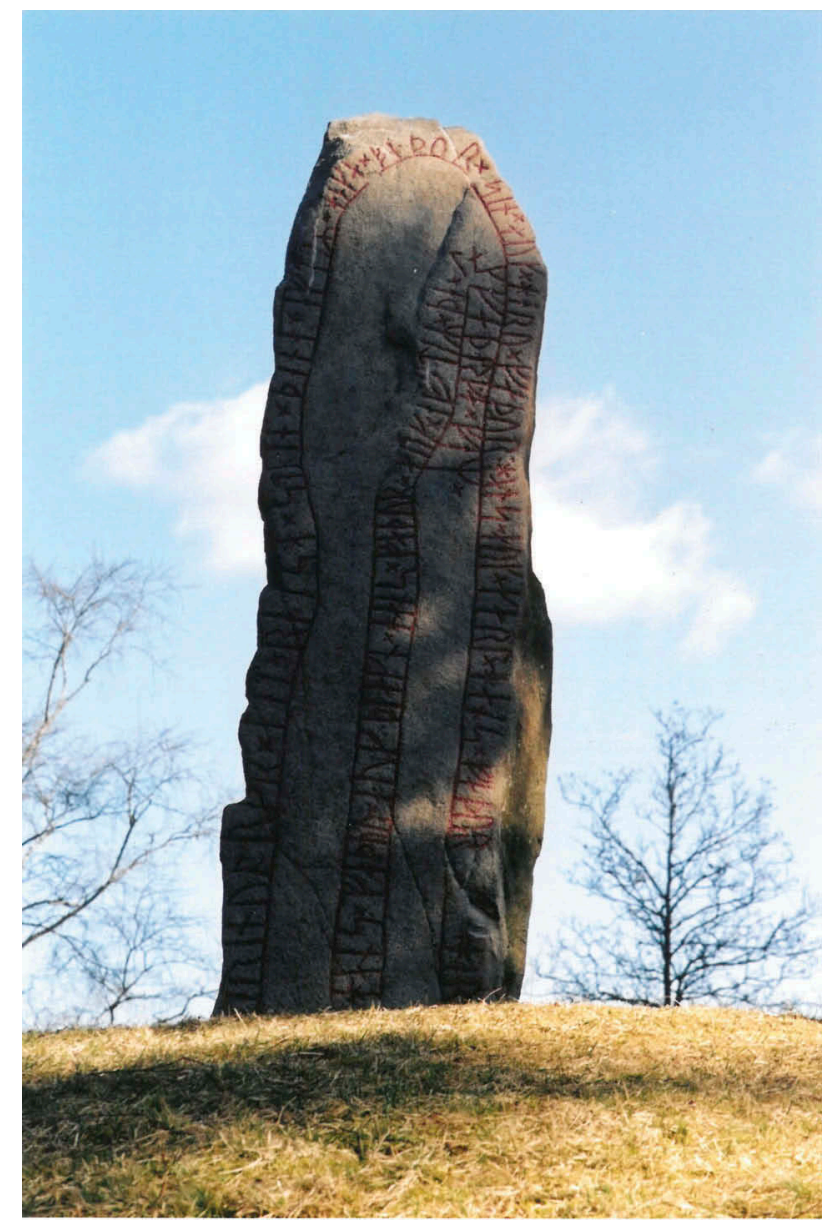

Figure 3. The Norra Sandsjö runestone (Sm 71). Photo: Linus Blohmé, 2001. archaeologists who made excavations in the fields. The change in farming system that they mirror occurred in the late Vendel Period/Viking Age $\left({ }^{14} \mathrm{C}\right.$-datings $678 \pm 80,891 \pm 70 \mathrm{CE}$, Gren 2003, p. 150f). These landscape changes may ultimately have been why Ärinvard had to sponsor an unconventional runic inscription: Arinvarðr let reeisa stoin penna oftiR Hogga, faður sinn, ok Horu, faður hans, ok Karl, hans faður, [ok] Horu, hans faður, ok Piagn/Pegn, hans faður, ok oftiR pa langfeðrga foem. 'Ærinvarðr had this stone raised in memory of Heggi, his father and Hæra, his (i.e. Heggi's) father, and Karl, his (i.e. Hæra's) father and Hæra, his father and Pegn, his father and in memory of these five forefathers'.

Ärinvard acted as if his odal rights were questioned and enumerated his five forefathers. This is further underlined by the expression langfoerga form, which can be translated 'persons that follow after each other, son after father in the same lineage for five generations'. In Icelandic Medieval literature, the word Old Norse langfoegar was used for genealogies (Sundqvist 2002, p. 153f). Ärinvard is thus the sixth generation and presumably the first generation that had odal right. When counting hypothetical generations forward from the transformation of the agrarian landscape (i.e. oldest ${ }^{14} \mathrm{C}$-datings \pm 80 years) to the supposed dating of the runestone, Ärinward could quite possibly have belonged to the sixth generation. His personal name also differs from the other male relatives in the genealogical chain. Karl and Thegn can be titles or personal names, Hära means old age and Hägge, the bird-cherry tree (Peterson 2007, cf. Zachrisson 2002, p. 36f). Ärinvard's name in contrast is interpreted as eagleguardian (Peterson 2007), a name that gives elite associations. Hunting with trained birds of prey was introduced in the Late Roman and Migration period, but normally goshawks and falcons were used. Using eagles was much more demanding, it was an equestrian technique that was imported from the east in the Viking Age. Bones of eagles are found in three high status male cremation burials from tenth century in Midsweden (Zachrisson 2002, 2010).

In Hälsingland, $650 \mathrm{~km}$ away from Sandsjö, HæGylfe, the father of Hromund, claimed and owned land as is described in a complicated runic inscription on the Malsta stone, recently interpreted anew 


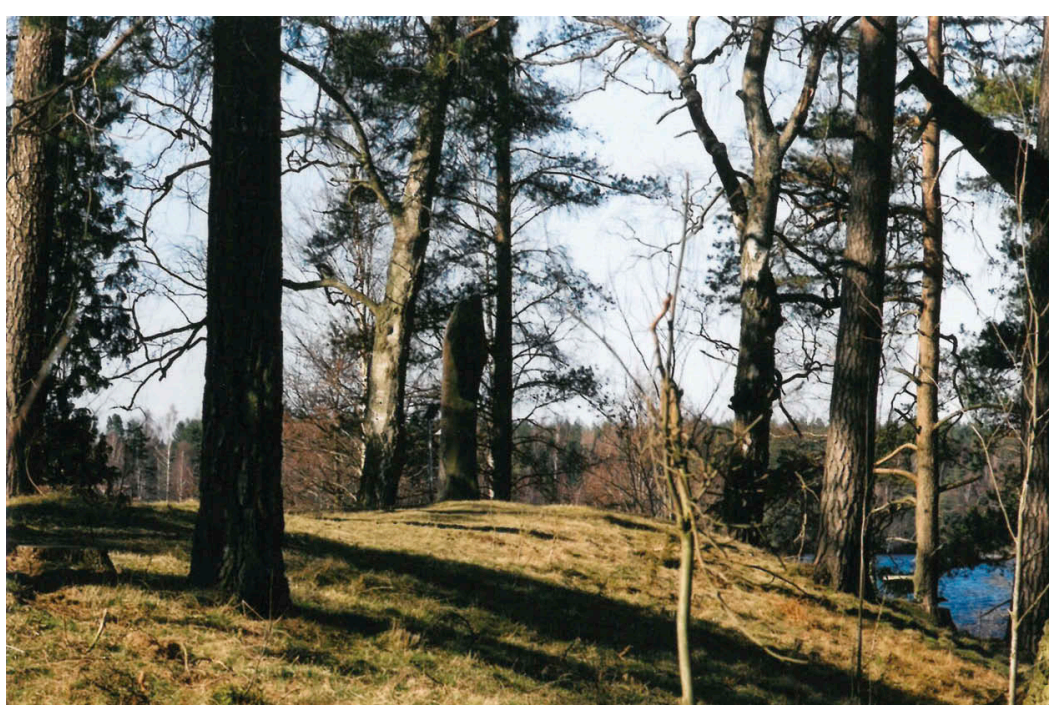

Figure 4. The runestone is standing on the ridge Runåsen. Photo: Linus Blohmé, 2001.

by Lena Peterson (2012): 'Hrō(ð)mundr erected this/ these stone/s in memory of Hé-Gylfir, Brīsi's son. And Brīsi was Lini's(?) son. And Lini(?) was Unn's son. And Unn was Ófeigr's son. And Ófeigr was Pórir's son. Grōa was Hé-Gylfir's mother. And Berglọ. And Guðrūn. Hróðmundr, Hé-Gylfir's son coloured these runes. We sought this stone in the north in Balasteinn. Gylfir acquired this land and then in Vika in the north /further north three estates, and then Lønangri and then Feðrasjór' (after Peterson 2012, cp. Åhlén 1994). The five ancestors of Hæ-Gylfe are enumerated: Brīsi, Lini, Unn, Ofeg and Tore. In the two provincial laws from Sweden, the Uppland Law (1290) and the Hälsinge Law (c. 1320-1350), on the enactment on how to inherit property and who inherited from whom, the law says: 'This is the inheritance procedure until the fifth line or generation' (Brink 2002, p. 103-5, Samling af Sweriges Gamla Lagar Ä11, Svenska landskapslagar, $\ddot{\mathrm{A}} 11)$.

There exists a Runic Swedish word langmøðrgu $(R)$, female ancestors in three generations that probably was the female counterpart to the langfoðragaR. This type of female line is alluded to in a runic inscription from Södermanland, from the deserted church of Ärja (Sö176C). The inscription was probably once placed on one of the slabs of a stone-cist, a very unusual monument for Viking Age in Middle Sweden. The inscription was carved with short-twig runes and probably dates as early as to $c .900 \mathrm{CE}$. It states: '.. each of the three ancestresses has six children, the best "En hvoriaR aigu langmøðrgu
priāR barn siax, boezt"'. This female line has been compared with a similar, cautiously suggested, ancestral maternal line in the Malsta inscription above consisting of three generations of females: Groa, Berglov, and Gudrun (Källström 2013, 152-153, cp. Peterson 2012).

\section{The late Viking Age runestone tradition}

Late Viking Age runestones belong in a Christian memorial tradition. The inscription, the materiality of the monument and its context together form and communicate the memory of deceased relatives. Nevertheless, runestones do almost exclusively convey a male memory (Sawyer 2002, p. 65), as if there were few women worthy enough to be commemorated. Birgit Sawyer has argued that runestones were intimately linked to inheritance rights of landed property (Sawyer 1988, 2000). She has identified a Danish-Norwegian-West Swedish pattern, and a contrasting East-Swedish-pattern where often several sponsors raised runestone together and women were more often included (Sawyer 2002, p. 66-68). But, it has recently been shown (Ljung 2016) that who is commemorated in the runic inscriptions changes over time as the runestone tradition moves from a landscape setting within a farm domain, to runic inscribed grave monuments erected at early Christian churchyards. In a landscape setting, the runestone was in contact with the landed property of the farm and a male memory expressing honourable deeds and qualities was communicated, and 
distant relatives and in-laws were also mentioned. In a landscape setting, it was also quite normal for a man to be mentioned by his first name and the name of the farm that he was connected to, as some eleventh century runic inscriptions show: Björn in Granby (U338), Ugg in Svanby (U1146), Torsten in Skyttinge (Sö84) and Gunnar's son in Rissne (U382, Peterson 2007, p. 310-325). Women however were never commemorated by this type of reference. When in a churchyard context on the other hand, the runic inscriptions to a larger extent included women, but were restricted to the closest family relations and very rarely contained information on honourable qualities and such (Ljung 2016). To directly relate the general figures for all types of Late Viking Age runic inscriptions to inheritance patterns without a closer look at the contexts for them, therefore leads wrong. In the churchyards, grave monuments with runic inscriptions were placed over both men and women, and consequently, women then became truly visible, even though a majority of the deceased and sponsors of monuments still were men (Ljung 2016, p. 235).

\section{The importance of family burial grounds in Mid-Sweden}

During the tenth century, remarkably many grave mounds were erected in the whole of the Mälar Valley, especially in the part north of the lake Mälaren. This movement must have involved the entire landowning group (Bratt 2008, p. 174). Traditionally, grave mounds were erected over men since the sixth century, and this was still the case when men were buried alone in the tenth century (Bratt 2008, p. 74). Altogether this indicates that the social group behind the grave mounds, most probably free landowners, had been enlarged in the tenth century and opened up to include also new groups that earlier used to have been excluded.

At the same time, there occurred a reuse of earlier graves at the burials grounds, where later burials were placed on top of older graves; ritual actions that sought to connect with the past. These superimpositions were not randomly made, but formed patterns in time and space. The tradition started as a rare phenomenon during the Migration Period (400-550 CE) and became very common first during the tenth and eleventh centuries. It took place in the whole Mälar Valley and did not occur on 'shortlived' farms, but in the final phase of burial grounds established in Roman times or earlier, thus at settlements with a long continuity of often 500 years. The individuals in the overlying graves as well as in the underlying grave stood out from contemporary graves on the cemeteries and sometimes in the region. These individuals must, judging by their grave goods, have had high social positions, and thus inhabited prosperous farms. The times that were linked through the superimposition could cover considerable time distances, often coinciding with a hypothetical living memory of five generations (Hållans Stenholm 2006, 2012, p. 118).

The fact that the superimpositions show common patterns, Ann-Mari Hållans Stenholm argues, suggests that these 'were formal acts'. The tradition expressed cultural memories tied to certain historical individuals probably known by name, that were part of the social landscape of the living and dead belonging to the ancient farms (Hållans Stenholm 2012, p. 244). These farm owners seem to have been obsessed with commemoration rituals at their burial grounds, and Hållans Stenholm calls it 'memory mania'. The rise in the number of superimpositions in the tenth century could be explained as a social stress and reaction of the householders at these ancient farms who saw that their rights were questioned, or diminishing. In the tenth century, a large influx of Islamic silver also opened up possibilities to purchase land as runic inscriptions like the Veda-rock in Angarn, Uppland shows (U209, Zachrisson 1994, p. 235), which may have added to the tension in the group of landowners. Hence, it seems likely that the group of ancient farms engaged in commemoration rituals identified by Hållans Stenholm could be the very same that held property rights expressed as old odal in the runic inscriptions from the early eleventh century.

\section{Regional burial rights}

A few burial mounds were built in the fourth century in central Sweden, but the fifth century seems to be the breakthrough for the mounds (Bennett 1987a, p. 73). After a climate crisis in the 530s and 540s, monumental mounds started to be built. This first generation of large mounds was especially monumental and linked to specific sites, such as the 
royal seat Old Uppsala (Bratt 2008, p. 63f, Ljungkvist $2008,2013)$. It is known in the written sources as the seat of god Freyr and his descendants, the illustrious Ynglingar (Sundqvist 2002). The claim for legitimacy that the monumental kings mounds of old Uppsala express suggests that these claims were considerably greater and mirrored the establishment of a royal genealogy where property claims were related to a realm (Gurevich 1985, p. 198, Sundqvist 2002, p. 174, Zachrisson 2011a, p. 149, 2011b, p. 111). It can be compared with the claim to the ownership of different farmlands in the rural landscape. In the burial grounds of ordinary Iron Age settlements, the clearly coped burial mounds occur from the Early Vendel Period, c. $550 \mathrm{CE}$ and onwards, very typical of Late Iron Age in central Sweden (Bennett 1987a, p. 21, 185). These coped mounds are constructed to be manifest and distinct in the landscape (Figure 5) and can be interpreted as expressing property claims. It seems reasonable to assume that at the erfi feast of the farm, the ancestors of the dead farm holder were enumerated, and that this had legal implication for the inheritance as a way of securing and legitimizing the succession of the farm.

Settlement changes were seen in Scandinavia in the wake of a climatic crisis, several volcanic eruptions, that occurred over a ten-year period with a start in 536-537 CE and had global impact (Gräslund 2007, Gräslund and Price 2012, Büntgen et al. 2016). This change may have had social consequences. Daniel Löwenborg (2012) assumes that there was a property right called odal in Midsweden before the social changes took place in the 500s. These property rights may have been redefined after the 530s, when there would also have been increased opportunities for private ownership of land. Bo Gräslund, on the other hand, views the strict requirements that seem to surround the early medieval odal rights, as a metaphor for ancient rights in general, which in practice had no significance other than when claiming rights to land, that had been deserted during the mid 500s (Gräslund 2012).

In the Early Iron Age, not all of the population was worthy of visible graves, but there was a balance between the males, females and children that were interred, roughly about one third of each group (e.g. Ljung 2001, Mejsholm 2009, p. 150). After c. 550, the pattern is very different, nearly no children at all were given a burial that left traces possible for archaeologists to detect (Mejsholm 2009, p. 153, 254-255). This together with the fact that especially men were buried in mounds and generally in graves that were of larger and more visible dimensions than those of the women underlines that male burials were made manifest in the landscape (Bennett 1987a, 1987b, Bratt 2008). Normally, the burial ground was placed within sight from the contemporary farm (Ambrosiani 1964). During the Late Iron Age, the farms were stationary in the

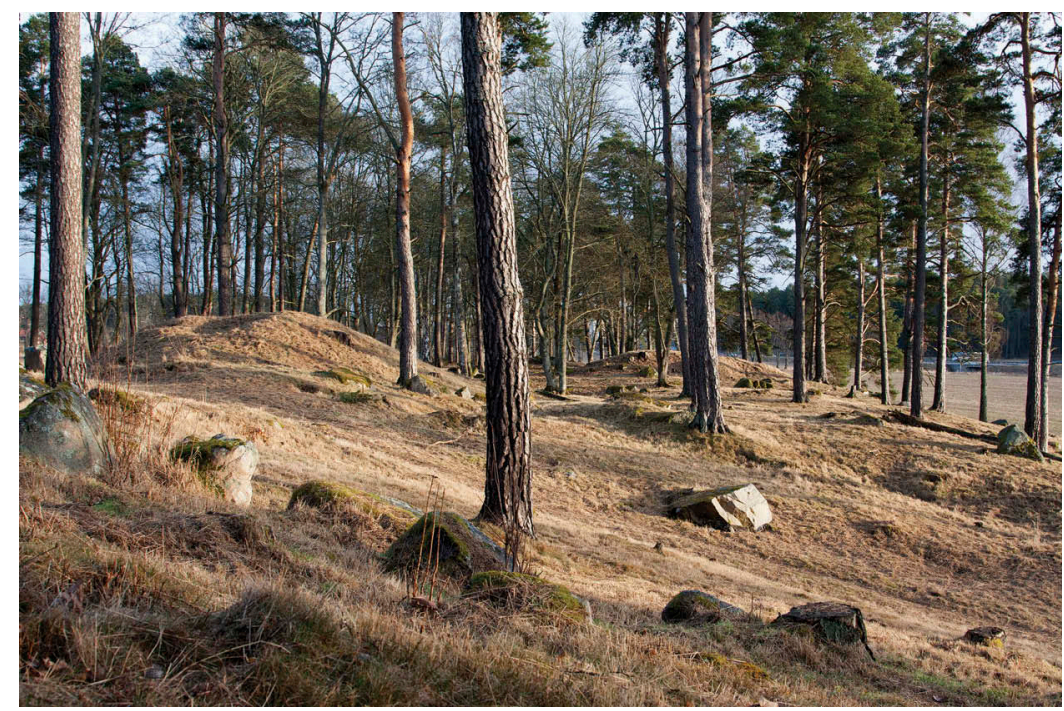

Figure 5. A burial ground from the Late Iron Age at Hammarby, Hammarby parish, Uppland characterized by its grave mounds (Raä Hammarby 54:1). Photo: Tomas Carlberg, 2016. 
landscape (Göthberg 2000), indicating that the land was not split when inherited, but the family domain connected with the burial ground was kept intact. This goes well in hand with a society that favours genealogies and male lineages connected to a family burial ground, and strongly indicates that there were formalized regulations when a farm holder died and his landed property was moved on to the next farm holder in succession. The burial mound seems to have played an important role in the legitimacy requests in the provincial laws from the Middle Ages when property rights were questioned. Claims from the villages with burial mounds of old age from pagan times had priority over the requests from younger settlements (Selinge 1980).

My conclusion is that the concept odal is old and connected to inherited land. In Midsweden, it can be set in a Late Roman Iron Age context, intimately connected with the farm burial grounds of ancient and prosperous farms that remained in use from $c$. $300 \mathrm{CE}$ up to the Late Viking Age and Christian times c. 1000-1100 CE (cf. Bennett 1987b, p. 154-155, Zachrisson 1994, p. 231). As Löwenborg rightly states, the large-scale events in the 530- and 540s with possible famines must seriously have affected the property rights, whether or not the Justinian plague also hit the Nordic countries. But the climatic crisis was not responsible for all social changes. Many lay already in the society that preceded it, but the climatic crisis could probably function as a catalyst, making the changes more profound than they otherwise would have been.

As a more formalized property right in the sense that it is alluded to in early medieval laws and runic inscriptions, the odal rights can be traced back to the societal changes around c. $550 \mathrm{CE}$ following the climatic crisis. The beginning of the Vendel period saw much of the same economic boom as in the aftermath of the Black Death (Andrén 2014, p. 178-183). Property rights probably had to be renegotiated in a much more hierarchal society. $C$. 550-600 CE, the royal seat of old Uppsala in Midsweden was monumentalized with several large halls built on artificial plateaus and likewise monumental burial mounds, stating large claims of power. A $500 \mathrm{~m}^{2}$ huge hall building has been excavated that was erected during the period of intense contacts with realms abroad. Archaeology shows that the milieu in Old Uppsala had information and networks addressing the region that they represented, but also alluding to elite behaviour on an overregional geographic scale. The large assembly that took place in Old Uppsala for all Svear (Andersson 2004, for the svear, Nordberg 2006, for the assembly), the people of Mid-Sweden must also have been important as a mediator when formalizing land rights. This larger realm and new social setting, where mounds were so regularly built at the Late Iron Age burial grounds at the same time as children practically 'disappeared' from the burials, indicate that the property rights were formalized in the society that emerged in the Vendel period and Viking Age (550-1050 CE).

\section{Property rights in Southern Scandinavia}

The mound seems in Scandinavia to have been especially connected with property rights (cf. Skre 1998, p. 199-212) and much of what has been synthesized for the development in central Sweden has parallels in Norwegian contexts, although there burial mounds were built almost continuously from the Bronze Age and onwards (cf. Ringstad 1991, Bratt 2008). In Denmark, grave mounds were more rarely constructed during the Late Iron Age than in Norway and Sweden, but could occur in special social settings as in Jelling. Thus, property rights in relation to Late Iron Age burials and burial grounds have not been the focus of a similar discussion in Denmark. However, property rights in relation to Iron Age settlements have been discussed by several Danish archaeologists. The theme has especially been addressed by Mads Holst (2004); summarized 2010) in his thesis on the development of the large Iron Age villages on Jylland. For the household, family, inheritance and marriage restrictions played a vital role. Holst makes a simple model for how these principles could have been translated in the landscape, by using Germanic laws as analogies (Holst 2004, p. 197). It is assumed that each household had individual rights to a plot in the ownership system, which can be seen archeologically, and that these rights were subject to the same development as other property in connection with marriage and inheritance. Another assumption is that property was not split into smaller parts, as there are no 
archaeological traces of such. A third assumption is that every new household formed by marriage was given the right to establish a new farm. This right did not have to be released immediately. The bilateral system, where the inheritance was distributed according to the real estate principles, resulted in a constant redistribution of land within the village community. All in all, the model can explain the dynamics of the constant redevelopment of farms and the abandonment of others, as well as the spread of farms in the domain over time. And, Holst emphasizes, this occurs without the intervention by any external control or superior power (2004, p.198).

Early on in the Pre-Roman Iron Age, one did not seem to have manipulated the ownership. But, the archaeological material seems to indicate that there gradually was a desire to keep the farm's property undivided by different marriage and heritage strategies. A strategic possibility was to allow inheritance of land to go to a limited number of individuals, for example sons. Several of the Germanic laws also indicate that there was an increased emphasis on the patrilineal side. Thus, during the course of the Iron Age, there probably was a shift from bilateral elements in the family inheritance to patrilineal (Holst 2004, p. 199-200). The large long houses that occur archaeologically also seem to indicate this, as more than one household probably inhabited them. Gradually, land accumulated through strategic thinking within the village system; changes were taking place and some farms grew. Those who stuck to the old way of forming new households with new farms scattered within the properties would slowly witness their property shrink, and land would gradually be transferred to the group representing the new strategies. During the Vendel period (c. 550-750 CE), according to Holst, some farms grew larger, while there were also small farms with short duration. The large manorial estates that occur during the Viking Age and early medieval period can be viewed as a continuation of the development where land was accumulated on ever fewer hands. Several of these processes later form the basis for the early medieval aristocracy (Holst 2004, p. 200). Holst does not associate these patterns with the odal right, but the strategic development and the gradual growth of certain domains that favour undivided land and strategic family planning could well be discussed against such a background.

\section{Notes}

1. The current Swedish term odal will hereafter be used in this paper.

2. The runic inscriptions in the article are translated into English according to the Scandinavian Runic-text Database, free to download from the website at the Dept. of Scandinavian Languages, Uppsala University, available from: http://www.nordiska.uu.se/forskn/sam nord.htm

\section{Disclosure statement}

No potential conflict of interest was reported by the authors.

\section{Funding}

This work was supported by the Riksbankens Jubileumsfond (SE) [P2007-1063:1-E].

\section{References}

Åhlén, M., 1994. Runinskrifter i Hälsinglands runinskrifter. Bebyggelsehistorisk tidskrift, 27, 33-50.

Ambrosiani, B., 1964. Fornlämningar och bebyggelse. Studier $i$ Attundalands och Södertörns förhistoria. Uppsala: Almqvist \& Wiksell.

Andersson, T., 2004. Svethiudh, det svenska rikets kärna. Namn och bygd, 92, 5-18.

Andrén, A., 2014. Tracing old norse cosmology. The world tree, middle earth and the sun in archaeological perspectives. Vägar till Midgård 16. Lund: Nordic Academic Press.

Bennett, A., 1987a. Graven - religiös och social symbol. Strukturer $i$ folkvandringstidens gravskick $i$ Mälarområdet. Theses and papers in north-European Archaeology 18. Stockholm: Stockholms Universitet.

Bennett, A., 1987b. Mälarområdets järnåldersgravfält. In: T. Andræ, M. Hasselmo, and K. Lamm, eds. 7000 år på 20 år. Arkeologiska undersökningar i Mellansverige. Stockholm: Riksantikvarieämbetet, 143-164.

Bratt, P., 2008. Makt uttryckt i jord och sten. Stora högar och maktstrukturer $i$ Mälardalen under järnåldern. Stockholm: Stockholm studies in archaeology.

Brink, S. and Collinson, L., eds., 2014. New approaches to early law in Scandinavia. Acta Scandinavica 3. Turnhout: Brepols.

Brink, S., 2002. Law and legal customs in Viking Age Scandinavia. In: J. Jesch, ed. The Scandinavians from the Vendel Period to the tenth century: an ethnographic perspective. Woodbridge, UK: Boydell Press, 87-116.

Brink, S., 2005. Verba Volant, Scripta Manent? Aspects of Early Scandinavian Oral Society. In: P. Hermann, ed. Literacy in medieval and early modern Scandinavian Culture. Odense: University Press of Southern Denmark, 77-135. 
Büntgen, U., et al., 2016. Cooling and societal change during the Late Antique Litte Ice Age from 536 to around 660 AD. Nature Geoscience, 1-7. doi:10.1038/NGEO2652

Cöllen, S., 2011. Der rätselhafte Gott. Himdallr im Licht altnordischer Vorstellungen von Ahnen und Ordnung. Uppsala: Uppsala universitet.

de Vries, J., 1961. Altnordisches etymologisches Wörterbuch. Leiden: Brill.

Düwel, K., 2001. Runenkunde. 3d ed. Stuttgart: J. B. Metzler. Eriksson, O. and Strid, J.P., 1991. Runstenar. Malmö: Edition Eriksson.

Heimskringla, 1893-1900. Noregs konunga sogur af Snorri Sturluson. In: F. Jonsson, ed. Samfund til Udgivelse af Gammel Nordisk Litteratur. København.

Fischer, S., 2005. Roman imperialism and Runic Literacy. The Westernization of Northern Europe (150-800 AD). Aun 33. Uppsala: Uppsala Universitet.

Foote, P.G. and Wilson, D.M., 1970. The Viking achievement. The society and culture of medieval Scandinavia. London: Sidgwick \& Jackson.

Gelting, M., 2000. Odelsrett - lovbydelse - bördsrätt - retrait lignager - Kindred and Land in the Nordic Countries in the twelfth and thirteenth centuries. In: L.I. Hansen, ed. Family, marriage and property devolution in the Middle Ages. Tromsø: Department of History, University of Tromsø, 133-165.

Göthberg, H., 2000. Bebyggelse i förändring. Uppland från slutet av yngre bronsålder till tidig medeltid. Uppsala: Uppsala Universitet.

Gräslund, A.-S., 1992. Runstenar - om ornamentik och datering II. Tor - tidskrift för nordisk fornkunskap, 24 (1992), 177-202.

Gräslund, A.-S., 2002. De senvikingatida runstenarna i Jönköpings län - deras ornamentik och datering. In: J. Agertz and L. Varenius, eds. Om runstenar i Jönköpings län, Småländska kulturbilder. Jönköping: Jönköpings länsmuseum, 139-155.

Gräslund, B., 2007. Fimbulvintern, Ragnarök och klimatkrisen år 536-537 e.Kr. Saga och Sed, 2007, 93-123.

Gräslund, B., 2012. Comments on Löwenborg. Journal of Archaeology and Ancient History, 2012 (4), 3-29.

Gräslund, B. and Price, N., 2012. Twilight of the gods? The 'dust veil event' of AD 536 in critical perspective. Antiquity, 86, 428-443. doi:10.1017/ S0003598X00062852

Gren, L., 2003. Hackerör i Njudungs västra härad: regional analys och detaljstudier i Norra Sandsjö'. In: M. Wigren, ed. Röjningsröseområden på sydsvenska höglandet, Arkeologiska, kulturgeografiska och vegetationshistoriska undersökningar. Stockholm: Kulturgeografiska institutionen, Stockholms universitet, 113-168.

Gurevich, A.J., 1985. Categories of medieval culture. London: Routledge \& Keagan Paul.

Gurevich, A.J., 1992. Historical Anthropology of the Middle Ages. J. Howlett, ed. Cambridge: Polity Press.

Gustavson, H., 1995. Runinskrifterna i Rannsakningarna den epigrafiska relevansen. In: E. Baudou and J. Moen, eds. Rannsakningar efter antikviteter, ett symposium om 1600-talets Sverige. Kungliga Vitterhets historie och antikvitetsakademien konferenser 30. Stockholm: Almqvist \& Wiksell International, 113-124.

Hafström, G., 1962. Jordegendom. In: J. Granlund ed. Kulturhistoriskt lexikon för nordisk medeltid, Vol. 7. Malmö: Allhems förlag.

Hållans Stenholm, A.-M., 2012. Fornminnen. Det förflutnas roll $i$ det förkristna och kristna Mälardalen. Vägar till Midgård 15. Lund: Nordic Academic Press.

Hållans Stenholm, A.-M., 2006. Past memories. Spatial returning as ritualized rememberance. In: C. Raudvere, K. Jennbert, and A. Andrén, eds. Old Norse religion in long-term perspectives. Origins, changes and interactions. An international conference 2004 June 3-7, Lund, Sweden. Lund: Nordic Academic Press, 341-345.

Helle, K., 2001. Gulatinget og Gulatingslova. Leikanger: Skald.

Holst, M.K., 2004. The syntax for the Iron Age village. Transformations in an orderly community. Unpublished thesis (PhD). Aarhus university.

Holst, M.K., 2010. Inconsistancy and stability. Large and small farmsteads in the village of Nørre Snede (Central Jutland) in the first millenium AD. Siedlungs- und Küstenforschung im südlichen Nordseegebiet, 33, 155-179.

Iversen, F., 2004. Eiendom, makt og statsdannelse. Kongsgårder og gods $i$ Hordaland $i$ yngre jernalder og middelalder. Bergen: Universitetet i Bergen.

Källström, M., 2013. Recension av L. Peterson, »En brisi vas lina sunn, en lini vas unaR sunn ... En pa barlaf...». Etymologiska studier över fyra personnamn på Malstaoch Sunnåstenarna i Hälsingland (2012). Studia anthroponymica Scandinavica, 31 (2013), 150-153.

Krövel, H.J., 2001. Minneinskrifter på runesteinar som historisk kjeldemateriale. Ein studie med utgangspunkt i innskrifter frå Noreg. Hovedfagsoppgave. Norges TekniskNaturvitenskapelige universitet, Trondheim.

Lamm, J.P., 2006. Uppsa kulle. Reallexikon der germanischen Altertumskunde, 31, 530.

Lantmateriet, historical maps from Runtuna, Inneberga village 1687, Lantmäteriet C 61, and Eneby village from 1769, C. Available from: www.lantmateriet.se/historiska kartor

Lindkvist, T., 1979. Landborna i Norden under äldre medeltid. Acta universitas Upsaliensis. Studia historica Upsaliensia 10. Uppsala: Uppsala Universitet.

Ljung, C., 2001. Liv, död och genus. Sociala konstruktioner speglade $i$ ett gravmaterial från Mälardalen. Seminar paper. Arkeologi \& Antik historia. Uppsala Universitet.

Ljung, C., 2016. Under runristad häll. Tidigkristna gravmonument i 1000-talets Sverige. Stockholm studies in archaeology, 67, 1-2.

Ljungkvist, J., 2008. Dating of the two royal mounds of Old Uppsala. Evaluating the elite of the 6th-7th century in Middle Sweden. Archäologisches Korrespondenzblatt, 38, 263-282.

Ljungkvist, J., 2013. Monumentaliseringen av Gamla Uppsala. In: O. Sundqvist and P. Vikstrand, eds. Gamla 
Uppsala i ny belysning. Religionsvetenskapliga studier från Gävle 9. Uppsala: Swedish Science Press, 33-68.

Löwenborg, D., 2012. An Iron Age Shoch Doctrine - Did the AD 536-537 event trigger large-scale social changes in the Mälar Valley? Journal of Archaeology and Ancient History, 2012 (4), 3-29.

Magnus Lagabøters Landslov, 1915. A. Taranger transl. Kristiania.

Mejsholm, L., 2009. Gränsland. Konstruktion av tidig barndom och begravningsritual vid tiden för kristnandet $i$ Skandinavien. Opia 44. Uppsala: Uppsala universitet.

$\mathrm{N}=$ Norges innskrifter med de yngre runer, 1954. Utgivet av M. Olsen under medvirkning av Aslak Liestøl, Vol. III. Oslo: Norsk historisk kjeldeskriftinstitutt.

Näsman, U., 2008. Från Attila till Karl den store. Skandinavien i Europa. In: M. Olausson, ed. Hem till Jarlabanke. Jord, makt och evigt liv i östra Mälardalen under järnålder och medeltid. Lund: Historiska media, 19-47.

Nelson, J. and Rio, A., 2013. Women and laws in early medieval Europe. In: J. M. Bennett and R. Mazo Karras, eds. The Oxford Handbook of women and gender in medieval Europe. Oxford: Oxford University Press, 104-117.

NGL $=$ Norges Gamle Love indtil 1387, Vol. I-III. Eds. R. Keyser \& P. A. Munch, (Christiania: 1846-49).

Nordberg, A., 2006. Jul, disting och förkyrklig tideräkning. Kalendrar och kalendariska riter $i$ det förkristna Norden. Kungliga Gustav Adolfs akademien. Uppsala: Swedish Science Press.

Nordiska kungasagor 2, 1992. Snorre Sturluson, översättning från isländskan av K. G. Johansson. Stockholm: Fabel.

Norseng, P., 1987. Lovmaterialet som kilde til tidlig nordisk middelalder. In: G. Karlsson, ed. Kilderne til den tidlig middelalders historie. Rapporter til den XX nordiske historiker kongres Reykjavik 1987, Vol. 1. Reykjavik: Sagnfræðistofnun Háskola Íslands, 48-77.

Öl=Ölands runinskrifter, 1900-06. Sveriges runinskrifter 1, granskade och tolkade av E. Brate and S. Söderberg. Stockholm.

Øye, I., 2002. Landbruk under press 800-1350. In: Norges landbrukshistorie I. Oslo: Samlaget, 215-414.

Peterson, L., 2006. Svenskt runordsregister. 3rd revised ed. Runrön 2. Uppsala: Uppsala universitet.

Peterson, L., 2007. Nordiskt runnamnslexikon. 5th revised ed. Uppsala: Institutet för Språk- och Folkminnen.

Peterson, L., 2012. En brisi vas lina sunn, en lini vas unaR sunn ... En Da barlaf". Etymologiska studier över fyra personnamn på Malsta- och Sunnåstenarna i Hälsingland. Sällskapet Runica et Mediævalia. Opuscula 15. Stockholm: Sällskapet Runica et Mediævalia.

$\mathrm{Raä}+\mathrm{nr}=$ Digital register for the ancient monuments of Sweden, National Heritage Board. Available from: http:// www.fmis.raa.se/cocoon/fornsok/search.html

Rannsakningar efter antikviteter, 1969. Vol. II, C. I. Ståhle, ed. Stockholm.

Ringstad, B., 1991. Graver og ideologi implikasjoner fra vestnorsk folkevandringstid. In: C. Fabech and J. Ringtved, eds. Samfundsorganisation og regional variation.
Norden i romersk jernalder og folkevandringstid. Beretning fra 1. nordiske jernaldersymposium på Sanbjerg slot 11-15 april 1989. Højbjerg: Jysk arkæeologisk Selskab.

Robberstad, K., 1967. Odelsrett. In: J. Granlund, ed. Kulturhistoriskt lexikon för nordisk medeltid, Vol. 12. Malmö: Allhems förlag.

Rønneseth, O., 1975. "Gard" und Einfriedigung. Entwicklungsphasen der Agrarlandschaft Jorens. Stockholm: Kulturgeografiska insitutionen, Stockholms Universitet.

Samling af Sweriges Gamla Lagar, 1827-44. Corpus Iuris Sueo-Gotorum Antiqui, Vols. 1-6, H.S. Collin and C. J. Schlyter, ed. Stockholm: Haeggström.

Sanmark, A., 2017. Viking law and order. Places and Rituals of Assembly in the North. Edinburgh: Edinburgh University Press.

Sawyer, B., 1988. Property and inheritance in Viking Age Scandinavia. Alingsås: Victoria.

Sawyer, B., 2000. Son skal taka arv efter far sin.... In: E. Mundal and I. Øye, eds. Norm og praksis $i$ middelaldersamfunnet. Bergen: Senter for europeiske kulturstudier, 56-79.

Sawyer, B., 2002. Runstenar och förmedeltida arvsförhållanden. In: J. Agertz and L. Varenius, eds. Småländska kulturbilder 2002. Om runstenar i Jönköpings län. Jönköping: Jönköpings länsmuseum, 5578.

Selinge, K.-G., 2010. Språket $i$ landskapet. Om runstenar, rågångar och byar. Stockholm: Kungl. Gustav Adolfs Akademien för svensk folkkultur.

Selinge, K.-G., 1980. Fra heidnum haugi eller vad kallades gravarna? In: Å. Hyenstrand, ed. Inventori in honorem. En vänbok till Folke Hallberg. Stockholm: Riksantikvarieämbetet, 288-297.

Sjöholm, E., 1988. Sveriges medeltidslagar. Europeisk rättstradition i politisk omvandling (Rättshistoriskt bibliotek 41). Stockholm: Institutet för rättshistorisk forskning.

Skre, D., 1998. Herredømmet. Bosetning og besittelse på Romerike 200 - 1350 e. Kr. (1st ed. 1996). Oslo: Scandinavian University Press.

Sm = Smålands runinskrifter, 1935-61. Sveriges runinskrifter 4, granskade och tolkade av R. Kinander. Stockholm: Almqvist \& Wiksell International.

Snorri Sturluson, 1964. Heimskringla. History of the kings of Norway. Translated by L.M. Hollander. Austin: University of Texas Press.

Snorri Sturluson, 1995. Edda. A. Faulkes, ed. London: Everyman.

Sö = Södermanlands runinskrifter, 1924-36. Sveriges runinskrifter 3, granskade och tolkade av E. Brate and E. Wessén. Stockholm: Almqvist \& Wiksell International.

Ståhle, C.I., 1956. Västgöta lagmanskväde. In: Archivistica et Mediaevistica Ernesto Nygren oblata. Stockholm: Norstedt, 408-423.

Ståhle, C.I., 1958. Syntaktiska och stilistiska studier i fornnordiskt lagspråk. Stockholm: Almqvist \& Wiksell International. 
Ståhle, C.I., 1965. Lagspråk. In: J. Granlund, ed. Kulturhistoriskt lexikon för nordisk medeltid. Malmö: Allhems förlag.

Struck, W.-H., 1990. Die Stifte St. Walpurgis in Weilburg und St. Martin in Idstein. Erzbistum Trier 6. Germania Sacra 27. Berlin: de Gruyter.

Sundqvist, O., 2002. Frey's offspring. Rulers and religion in ancient Svea society. Uppsala: Acta Universitatis Upsaliensis.

Sundqvist, O., 2016. An Arena for higher powers. Ceremonial buildings and religious strategies for rulership in Late Iron Age Scandinavia. Leiden: Brill.

Svenska landskapslagar, 1933-46. Tolkade och förklarade för nutidens svenskar av A. Holmbäck \& E. Wessén. Stockholm: A.W. Gebers, 1-5.

Taranger, A., 1913. The meaning of the words "oðal" and "skeyting' in the Old Laws of Norway. In: Essays in Legal History read before the International Congress of Historical Studies. London, New York: Oxford University Press, 159173.

$\mathrm{U}=$ Upplands runinskrifter, 1940-58. Sveriges runinskrifter, Vols. 6-9. Translated by S. B. F. Jansson and E. Wessén. Stockholm: Almqvist \& Wiksell International.

Vierck, H., 1981. Imitatio imperii und Interpretatio Germanica vor der Wikingerzeit. In: R. Zeitler, ed. Les pays du Nord et Byzance (Scandinavie et Byzance), actes $d u$ Colloque nordique et international de byzantinologie, tenu à Upsal 20-22 avril 1979. Uppsala: Almqvist \& Wiksell International.

Vikstrand, P., 2015. Aspa löt och Runtuna. Om Rönö hundares tingsplats. Saga och Sed, 2015, 41-66.

Vogt, H., 2010. The Function of kinship in medieval nordic legislation, Vol. 9, Medieval Law and Its Practise. Brill: Leiden.

Williams, H., 1996a. The origins of the runes. In: A. Quak and T. Looijenga, eds. Frisian runes and Neighbouring traditions. Amsterdamer beiträge für ältere germanistik. Amsterdam: Rodopi, 211-218.

Williams, H., 1996b. The Romans and the runes - uses of writing in Germania. In: S. Nyström, ed. Runor och abc. Elva föreläsningar från ett symposium $i$ Stockholm våren 1995. Stockholm: Sällskapet Runica et Mediævalia, Riksantikvarieämbetet, Stockholms medeltidsmuseum, 177-192.

Winberg, C., 1985. Grenverket. studier rörande jord, släktskapssystem och ståndsprivilegier. Stockholm: Institutet för rättshistorisk forskning.

Zachrisson, T., 1994. The odal and its manifestation in the landscape. Current Swedish Archaeology, 2, 219-238.

Zachrisson, T., 1998. Gård, gräns, gravfält. Sammanhang mellan ädelmetalldepåer och runstenar från vikingatid och tidigmedeltid $i$ Uppland och Gästrikland. Stockholm: Stockholms Universitet.

Zachrisson, T., 2010. Kungsämnen i Söderby och kungens Sigtuna. Om den materiella kulturen i och kring Söderby i Danmarks socken. Situne dei, 2010, 163-175.

Zachrisson, T., 2011b. Fjärran ting - exotiska föremål och nya seder i Mellansverige ca 550-700 e.Kr. In: A. Andrén, ed. Förmodern globalitet. Essäer om rörelse, möten och fjärran ting under 10.000 år. Lund: Historiska media, 109-129.

Zachrisson, T., 2002. Ärinvards minne - om runstenen i Norra Sandsjö. In: J. Agertz and L. Varenius, eds. Småländska kulturbilder 2002. Om runstenar i Jönköpings län. Jönköping: Jönköpings länsmuseum, 3554.

Zachrisson, T., 2011a. Property \& honour - social change in Middle Sweden 400-700 AD. In: L. Boye, ed. The development of leadership and Elites in the First Millenium AD. The 61st International Sachsensymposion 2010 in Haderslev. Arkæologi i Slesvig /Archäologie in Schleswig. Neumünster: Wachholtz Verlag, 141-156. 